\begin{tabular}{rr} 
çağdaş & Yaratıcı Drama Dergisi 2017, 12(2), 93-104 \\
drama & www.yader.org \\
\hline
\end{tabular}

\title{
Müze Eğitimi Alanında Yapılmış Tezler
}

\section{Ayșe Çakır İlhan ${ }^{1}$}

\begin{tabular}{|c|c|}
\hline Makale Bilgisi & $\ddot{\mathbf{O} z}$ \\
\hline DOI: $10.21612 /$ yader.2017.016 & $\begin{array}{l}\text { Çă̆daş müze; müze koleksiyonu, müze yönetimi ve müze çalışanı ile müze } \\
\text { ziyaretçisinden oluşan üç saç ayağ üzerine kurulmuştur. Birinci Dünya Savaşı'nın }\end{array}$ \\
\hline Makale Geçmişi & $\begin{array}{l}\text { ardindan basslayan çağdaş müze anlaylş alana yeni bakış açlarlar getirmiştir. } \\
\text { 1917'den 1950'li yıllara kadar müzede ögrenmenin gerekliligi ve önemi ile }\end{array}$ \\
\hline 30.05 .2017 & müzelerin üniversiteler gibi araștırma merkezleri olması fikri kabul görmeye \\
\hline 02.12 .2017 & $\begin{array}{l}\text { başlamıştır. } \\
\text { araştırarak kendisinin bilgi üretmesi gerekliliği vurgulanmıs, böylece müzeler, } \\
\text { laboratuvar ve kütüphaneler önem kazanmıştr. Bu bağlamda müzelerin toplumu } \\
\text { eğlendirecek ve eğitecek tarzda koleksiyonların kullanmaya başladığ gör gülür. } \\
\text { 1965'den sonra müzelerde kültür merkezleri kurulmaya, çok kültürlü egitim, müze }\end{array}$ \\
\hline Anahtar Sözcükler & $\begin{array}{l}\text { egitimi ve kültürel dersler ögretim programlarında yer almaya basslamıștır. Nesneler } \\
\text { hakkında akademik bilginin aktarımının yanında, toplumun farklı kesimlerinin }\end{array}$ \\
\hline Müze ĕ̆itimi & $\begin{array}{l}\text { özellikleri, insan gelişimi, iletişim teorileri, grup dinamizmi, kültürlerarasılık önem } \\
\text { kazanmıstır. Nesne temelli bilgi aktarımından nesnevi bağlamsal acıdan yorumlama. }\end{array}$ \\
\hline Müzecilik & deneyim oluşturma yaklaşımına geçilmiştir. 1990 'll yıllarda müze görevli kadrosuna; \\
\hline Lisansüstü tezler & 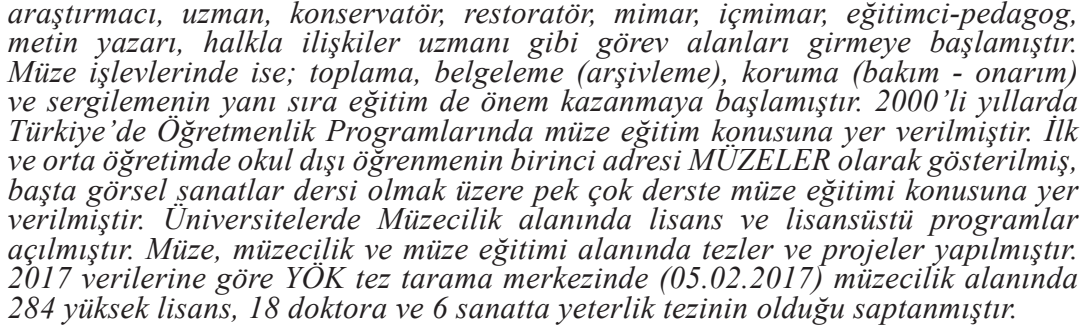 \\
\hline
\end{tabular}

\section{Thesis in the Field of Museum Education}

\begin{tabular}{lr}
\hline \multicolumn{2}{l}{ Article Info } \\
\hline DOI: $10.21612 /$ yader.2017.016 \\
\hline Article History & \\
Received & 30.05 .2017 \\
Accepted & 02.12 .2017
\end{tabular}

Keywords

Museum education

Museology

Postgraduate thesis

\begin{abstract}
The contemporary museum is based on a three legged stoolthat is made up of the collection, management and staff, and visitors. The new understanding of contemporary museums that begun after the First World War opened new perspectives in the field of museum. From 1917 to 1950, the necessity of museum learning and the idea of museums becoming research centers similar to universities started to become accepted. In 1950's developments in educational sciences, emphasizing the necessity of students being able to generate knowledge through research increased the importance of museums, laboratories and libraries. In this context, it is seen that the museums started to use their collections in a manner that will entertain and educate the society. After 1965, cultural centers started to be established in museums and multicultural education, museum education and cultural lectures were included in teaching programs. Besides the transfer of academic knowledge about objects, the characteristics of different parts of the society, human development, communication theories, group dynamism, inter-culturalism have gained importance. From the object-based knowledge transfer, the object has been changed from the contextual perspective to the experience creation approach. During the 1990s researchers, experts, conservators, restorers, architects, interior architects, educators-pedagogues, text writers, public relations experts were started to be included in museum staff. The function of the museums also expanded from collection, documentation (archival), protection (maintenance) and exhibition to education. In 2000, museum education was included in teaching programs in Turkey. MUSEUM, and many degree program sprimarily on visual arts included museum education in their programs. Undergraduate and post-graduate programs were opened in the field of museology in universities. Thesis and projects have been made in the field of museum, museology and museum education. According to 2017 data, 284 graduate, 18 doctorate and 6 artistic proficiency theses were found in the field of museology in YÖK (Turkish Higher Education Institute) thesis screeningcenter (05.02.2017).
\end{abstract}

$\overline{1}$ Prof. Dr., Ankara Üniversitesi Eğitim Bilimleri Fakültesi Güzel Sanatlar Eğitimi Bölümü/ Sosyal Bilimler Enstitüsü Disiplinlerarsı Müze Eğitimi Anabilim Dalı Başkanı, E-posta: Ayse.C.Ilhan@ankara.edu.tr. 


\section{Giriş}

Uluslararası Müzecilik Komitesi’ne göre müze eğitimi, izleyicinin gelişimini sağlamak amacıyla çeşitli değer, kavram ve bilgilerden yola çıkarak ve pedagojik yöntemler kullanarak geliştirilen bir kültürlenme sürecidir (ICOFOM, 2010). Bu kültürlenme süreci aynı zamanda etkili bir “okul dış1 eğitim” örneğidir. Müze eğitimi hem duyusal hem de entelektüel boyutları olan bir eğitimdir. 1917 yılından itibaren müzede öğrenmenin gerekliliği önem kazanmış, müzelerin üniversiteler gibi araştırma merkezleri haline getirilmesi vurgulanmaya başlanmıştır. 1950'lerde eğitim bilimlerinde yaşanan gelişmelerde, öğrencinin araştırarak kendisinin bilgi üretmesi gerektiği vurgulanmıştır. Böylece müzeler, laboratuvar ve kütüphaneler önem kazanmaya başlamıştır. 1950'lerde müzelerin toplumu eğlendirecek ve eğitecek tarzda koleksiyonlarını kullanmaya başladığı görülür. 1965'de müze kültür merkezleri kurulmaya başlanmıştır. 1970'li yıllarda özellikle sanat eğitimi alanında müzelerin kullanılması zorunlu kılınmıştır. Bu amaçla çok kültürlü eğitim, müze eğitimi ve kültürel dersler sanat eğitimi öğretim programlarına girmiştir.

1970’li yıllarda müze eğitimi anlayışında yenilikler kendini göstermiştir. Nesneler hakkında akademik bilginin aktarımının yanında, toplumun farklı kesimlerinin özellikleri, insan gelişimi, iletişim teorileri, grup dinamizmi, kültürler arasılık önem kazanmıştır. Nesne temelli bilgi aktarımından nesneyi bağlamsal açıdan yorumlama, deneyim oluşturma yaklaşımına geçilmiştir. 1990'lı yıllarda müze görevli kadrosuna; araştırmacı, uzman, konservatör, restoratör, mimar, içmimar, eğitimcipedagog, metin yazarı, halkla ilişkiler uzmanı gibi görev alanları girmeye başlamıştır. Müzelerin işlevleri arasında toplama, belgeleme (arşivleme), koruma (bakım - onarım) ve sergilemenin yanı sıra ve eğitimde önemli olmaya başlamıştır. Türkiye genelinde müze sayısı 2015 yılında 409'a ulaşmıştır. Bunların 193'si Kültür Varlıkları ve Müzeler Genel Müdürlüğü bünyesinde, 216's1 ise özel müze kategorisinde yer almaktadır. Kültür Varlıkları ve Müzeler Genel Müdürlügü bünyesindeki müzelerin tamamına yakını arkeoloji, etnografya, antropoloji ya da genel müze olarak faaliyet göstermektedir. Öte yandan müzede ziyaretçi ile buluşan teknolojik unsurlar, sanal müzecilik örnekleri, keşif odası vb. etkileşimli birimler Türkiye geneline henüz yeterince yaygınlaşmamıştır.

Müze eğitimi bu gelişmelerle birlikte ayrı bir uzmanlık ve eğitim gerektiren bir alan olmuştur. Bu nedenle pek çok ülkedeki üniversitelerde müzecilik ve müze eğitimi formasyonu veren bölümler açılmıştır. Müzelerin eğitim bölümlerinde müze eğitimi almış uzmanlar görevlendirilmeye başlanmıştır. Örneğin Amerika Birleşik Devletleri'nde müze eğitimi önceleri gönüllü müze derneklerinin emekli sanat tarihi, arkeoloji ve tarih öğretmenlerinin özel seminerlerle yetiştirilmesiyle gerçekleştirilmiş, daha sonra 1960'larda müzecilik yüksek lisans eğitimi görmüş müze eğitimcilerinin kadrolara alınmasıyla müzelerde eğitim bölümleri oluşturulmuştur. Türkiye'de de hem lisans hem de lisansüstü düzeyde Müzecilik ve Müze Eğitimi programları açılmaya başlanmıştır:

1. Yıldız Teknik Üniversitesi Müzecilik Yüksek Lisans Programı,

2. Ankara Üniversitesi Disiplinlerarası Müze Eğitimi Yüksek Lisans Programı,

3. İstanbul Üniversitesi Müze Yönetimi Yüksek Lisans Programı

4. Mimar Sinan Güzel Sanatlar Üniversitesi Müzecilik Yüksek Lisans Programı

5. Dokuz Eylül Üniversitesi Müzecilik Lisans ve Yüksek Lisans Programı

6. Akdeniz Üniversitesi Müzecilik Yüksek Lisans Programı

7. Başkent Üniversitesi Müzecilik Yüksek Lisans Programı vb. 
Aynı zamanda örgün eğitimde de müze eğitimine 2000'li y1llardan sonra büyük önem verilmeye başlanmıştır. 2005-2006 öğretim yılından itibaren Türkçe, matematik, fen ve teknoloji öğretimi gibi derslerde müzelerden yararlanılması gereği vurgulanmış, görsel sanatlar ve sanat etkinlikleri derslerinin programlarında müze eğitimi öğrenme alanı olarak ilköğretim birinci sınıftan sekizinci sınıfa kadar programın yaklaşık üçte birini oluşturmuştur. Anadolu Güzel Sanatlar Liselerinde "Müze Eğitimi” bir ders olarak okutulmaya başlamıştır. Öğretmenlik Programlarında (Sınıf Öğretmenliği, Sosyal Bilgiler Öğretmenliği, Resim Öğretmenliği vb. lisan programlarında) bazen zorunlu bazen de seçimlik ders olarak "Müze Eğitimi” dersi okutulmaktadır. Türkiye'de müzecilik alanında yaşanan tüm bu gelişmelere karşın müze eğitimi alanında eğitilmiş yeterli insan gücü yetiştirilememiştir. 2017 yılı itibari ile Türkiye' de Müzecilik alanında farklı çalışmalar olmasına karşın bir doktora programı mevcut değildir. Ancak farklı üniversitelerin lisansüstü programlarında lisansüstü düzeyde tezler yaptırılmaktadır.

26 Şubat 2017 YÖK Tez Taraması sonucunda 'Müzecilik' alanında 309 kayıt bulunmuştur. Bu tezlerin 285'i yüksek lisans, 18'i doktora ve 6's1 sanatta yeterlik tezidir. Müze eğitimi alanında ise 70 teze ulaşılmıştır (Ek:1). Bu araştırma kapsamında incelenen 70 tezin 9'u doktora, 61'i ise yüksek lisans tezidir. Tezler üniversiteye, yıla, konu alanına, örneklenen müzeye, çalışma alanına ve hedef kitleye göre tablo halinde verilmiştir.

\section{Müze Eğitimi Lisansüstü Tezlerinin Üniversitelere Göre Dağılımı}

\begin{tabular}{|l|l|}
\hline Üniversiteler & \\
\hline Gazi Üniversitesi & 16 \\
\hline Ankara Üniversitesi & 13 \\
\hline Marmara Üniversitesi & 7 \\
\hline Yıldı Teknik Üniversitesi & 4 \\
\hline Selçuk Üniversitesi & 4 \\
\hline Dokuz Eylül Üniversitesi & 4 \\
\hline Atatürk Üniversitesi & 2 \\
\hline Abant İzzet Baysal Üniversitesi & 1 \\
\hline Afyon Kocatepe Üniversitesi & 1 \\
\hline Akdeniz Üniversitesi & 1 \\
\hline Aksaray Üniversitesi & 1 \\
\hline Dumlupınar Üniversitesi & 1 \\
\hline Gaziosmanpaşa Üniversitesi & 1 \\
\hline İstanbul Arel Üniversitesi & 1 \\
\hline İstanbul Bilgi Üniversitesi & 1 \\
\hline İstanbul Kemerburgaz Üniversitesi & 1 \\
\hline Kafkas Üniversitesi & 1 \\
\hline Karadeniz Teknik Üniversitesi & 1 \\
\hline Kastamonu Üniversitesi & 1 \\
\hline Koç Üniversitesi & 1 \\
\hline Mimar Sinan Güzel Sanatlar Üniversitesi & 1 \\
\hline Necmettin Erbakan Üniversitesi & 1 \\
\hline On Dokuz Mayis Üniversitesi & 1 \\
\hline
\end{tabular}




\begin{tabular}{|l|l|}
\hline Sakarya Üniversitesi & 1 \\
\hline Selçuk Üniversitesi & 1 \\
\hline Uludă̆ Üniversitesi & 1 \\
\hline Kültür ve Turizm Bakanlığ 1 & 1 \\
\hline Toplam & $\mathbf{7 0}$ \\
\hline
\end{tabular}

Yukarıdaki tablo incelendiğinde müze eğitimi alanında yapılan lisansüstü tezlerin en fazla Gazi Üniversitesi ve Ankara Üniversitesi bünyesinde yapıldığı görülmektedir.

Müze Eğitimi Lisansüstü Tezlerin Yıllara Göre Dağılımı

\begin{tabular}{|l|l|}
\hline 2015 y1llarında & 15 \\
\hline 2009 y1llarında & 9 \\
\hline 2011 y1llarında & 7 \\
\hline $2008,2010,2012$ y1llarında & 6 \\
\hline 2007 y1lında & 4 \\
\hline $2014,2013,2006,2005$ y1llarında & 3 \\
\hline 2001 y1linda & 2 \\
\hline $2004,2002,2016$ y1llarında & 1 \\
\hline Toplam & $\mathbf{7 0}$ \\
\hline
\end{tabular}

Müze Eğitimi konusunda yapılan lisansüstü tezlerinin yıllara göre dağılımı incelendiğinde en çok 2015 yılında bu alanda tez yapıldığı saptanmıştır. Bu durum müze eğitimi alanın her geçen gün daha da önemsendiğini göstermektedir.

Müze Eğitimi Lisansüstü Tezlerin Konu Alanına, Örneklenen Müzeye, Çalışma Alanına ve Hedef Kitleye Göre Dağılımı

\begin{tabular}{|l|l|l|l|}
\hline Konu alanı & Örneklenen müze & Çalışma alanı & Hedef kitle \\
\hline Müze Eğitimi & Sanal müze & Çizgi Film & 7-12 Yaş \\
\hline Müze Eğitimi & Tokat Müzesi & $\begin{array}{l}\text { Sosyal bilgiler } \\
\text { programları }\end{array}$ & $\begin{array}{l}\text { Sosyal bilgiler } \\
\text { öğretmenleri }\end{array}$ \\
\hline Müzede Öğrenme & Çorum Müzesi & $\begin{array}{l}\text { Görsel, Duyuşsal ve } \\
\text { Kinestetik }\end{array}$ & 6. Sınıf Öğrencileri \\
\hline Müzede Öğrenme & \multicolumn{1}{|c|}{-} & Sanat Etkinlikleri Dersi & 3. Sınıf Öğrencileri \\
\hline Müze Eğitimi & - & Görsel Sanatlar Eğitimi & Sınıf Öğretmenleri \\
\hline Müze Eğitimi & - & Tarih Öğretimi & Tarih Öğretmenleri \\
\hline Müze Eğitimi & Çocuk Müzesi & Çocuk Müzesi & Çocuk Müzesi Modeli \\
\hline Kültürel Çeşitlilik & Arkeoloji Müzesi & $\begin{array}{l}\text { Müzede Kültürel } \\
\text { Çeşitlilik }\end{array}$ & $\begin{array}{l}\text { Müze Çalışanları ve } \\
\text { Eğitimciler }\end{array}$ \\
\hline Üniversite Ĕ̆itimi & Üniversite Müzeleri & Sanat Müzesi & Üniversite öğrencileri \\
\hline Gezici Bavul Müze & Çorum Müzesi & Gezici Bavul Müze & 6. Sınıf Öğretmenleri \\
\hline Müze Eğitimi & $\begin{array}{l}\text { Atatürk ve Kurtuluş Savaşı } \\
\text { Müzesi }\end{array}$ & Müze Eğitimi & Ziyaretçi Profili \\
\hline Müze Eğitimi & - & Sanat Eğitiminde & 5. Sınıf Öğrencileri \\
\hline
\end{tabular}


Müze Eğitimi Alanında Yapılmış Tezler

\begin{tabular}{|c|c|c|c|}
\hline Müze Eğitimi & - & $\begin{array}{l}\text { Disiplin Temelli Sanat } \\
\text { Eğitimi }\end{array}$ & Resim-İş Öğretmenleri \\
\hline Müze ve İletişim & $\begin{array}{l}\text { MSGSÜ Resim ve Heykel } \\
\text { Müzesi }\end{array}$ & Toplumsal İletişim & Müze Ziyaretçileri \\
\hline Görsel Sanatlar Eğitimi & Sanal Müze & $\begin{array}{l}\text { Sanal Sanat Müzeleri ve } \\
\text { Galerileri }\end{array}$ & $\begin{array}{l}\text { Görsel Sanatlar } \\
\text { Öğrencileri }\end{array}$ \\
\hline Müze Eğitimi & Sanal Müze & $\begin{array}{l}\text { Bilişsel ve Duyuşsal } \\
\text { Kazanımlar }\end{array}$ & Müze Ziyaretçileri \\
\hline Müze Eğitimi & Bilim Müzesi & Bilgi Hiyerarşisi & \\
\hline Müzede Eğitim & Kars Müzesi & Kültür, Tarih Alan Bilgisi & 7. Sınıf Öğrencileri \\
\hline Müze Eğitimi & - & Resim-İş Dersinde & Ortaokul Öğrencileri \\
\hline Müzede Öğrenme & Çocuk ve Gençlik Müzeleri & $\begin{array}{l}\text { Barış Eğitimi } \\
\text { Programları }\end{array}$ & Ortaokul Öğrencileri \\
\hline Müzede Öğrenme & Sanayi Müzeleri & Tarih Öğretimi & Lise Öğrencileri \\
\hline Müzede Öğrenme & $\begin{array}{l}\text { Anıtkabir Müzesi, Anadolu } \\
\text { Medeniyetleri Müzesi }\end{array}$ & Sanat Eğitimi & Ortaokul Öğrencileri \\
\hline Müze Eğitimi & Pera Müzesi & Sanatsal Gelişim & Ortaokul Öğrencileri \\
\hline $\begin{array}{l}\text { Müzeler ve Kültürel } \\
\text { Çeşitlilik }\end{array}$ & Modena Müzesi/İtalya & $\begin{array}{l}\text { Müzeler ve Kültürel } \\
\text { Çeşitlilik }\end{array}$ & Müze Ziyaretçileri \\
\hline $\begin{array}{l}\text { Müze Gezilerinin } \\
\text { Önemi }\end{array}$ & Arkeoloji Öüzeleri & $\begin{array}{l}\text { Kültürel Öğelerin } \\
\text { Öğretimi }\end{array}$ & Sınıf Öğretmenleri \\
\hline $\begin{array}{l}\text { Müze Eğitim } \\
\text { Programları Önerisi }\end{array}$ & Resim ve Heykel Müzesi & Müze-Toplum İletişimi & Sanat Eğitimcileri \\
\hline Sanal Müze Kullanımı & Sanal Müze & Sosyal Bilgiler Dersi & $\begin{array}{l}\text { Sosyal Bilgiler } \\
\text { Öğretmeni Adayları }\end{array}$ \\
\hline Müze Eğitim & $\begin{array}{l}\text { Anadolu Medeniyetleri } \\
\text { Müzesi }\end{array}$ & $\begin{array}{l}\text { Müze Yıllıklarındaki } \\
\text { Müze Eğitimi Konuları }\end{array}$ & \\
\hline Müze Eğitimi & $\begin{array}{l}\text { Çengelhan Rahmi Koç } \\
\text { Müzesi }\end{array}$ & $\begin{array}{l}\text { Müzesi Eğitim } \\
\text { Potansiyeli }\end{array}$ & - \\
\hline Müze Eğitimi & $\begin{array}{l}\text { MEB. 75. Y1l Cumhuriyet } \\
\text { Eğitim }\end{array}$ & $\begin{array}{l}\text { Müzesi ve Eğitim } \\
\text { Potansiyeli }\end{array}$ & - \\
\hline Müze Eğitimi & $\begin{array}{l}\text { Türk İslam Eserleri Müzesi } \\
\text { Rahmi M Koç Müzesi }\end{array}$ & $\begin{array}{l}\text { Sosyal Bilgiler } \\
\text { Öğretiminde Müze } \\
\text { Kullanımı }\end{array}$ & 4 ve 5.sınıf Öğrencileri \\
\hline Müze Eğitimi & - & $\begin{array}{l}\text { Müze Eğitiminin Görsel } \\
\text { Sanatlar Kültürüne } \\
\text { Etkileri }\end{array}$ & 4 ve 5.sınıf Öğrencileri \\
\hline Müze Eğitimi & Bolu müzeleri & $\begin{array}{l}\text { Görsel Sanatlar } \\
\text { Eğitimine }\end{array}$ & 7.sınıf Öğrencileri \\
\hline $\begin{array}{l}\text { Müzelerin Eğitim } \\
\text { Fonksiyonları }\end{array}$ & - & $\begin{array}{l}\text { Müze Yöneticilerinin } \\
\text { Tutum ve Fikirleri }\end{array}$ & Müze Yöneticileri \\
\hline Görsel Sanatlar Eğitimi & $\begin{array}{l}\text { Arkeoloji ve Etnografya } \\
\text { Müzeleri }\end{array}$ & $\begin{array}{l}\text { Tarihi Çevre ve Müze } \\
\text { Bilinci }\end{array}$ & Lise Öğrencileri \\
\hline
\end{tabular}




\begin{tabular}{|c|c|c|c|}
\hline Sosyal Bilgiler Öğretimi & - & $\begin{array}{l}\text { Sosyal bilgiler } \\
\text { öğretiminde müze } \\
\text { kullanımı }\end{array}$ & Öğretmen Adayları \\
\hline $\begin{array}{l}\text { Müze Eğitimine } \\
\text { Dayalı Öğretim } \\
\text { Uygulamalarının }\end{array}$ & - & $\begin{array}{l}\text { Akademik Başarı ve } \\
\text { Tutum }\end{array}$ & 7.sınıf Öğrencileri \\
\hline Müze Eğitimi & $\begin{array}{l}\text { İstanbul Modern Sanat } \\
\text { Müzesi ile Avusturya } \\
\text { Lentos Kunts MuseumLinz }\end{array}$ & $\begin{array}{l}\text { Eğitim Odaları } \\
\text { Etkinlikleri }\end{array}$ & - \\
\hline Müze Eğitimi & Trabzon Müzeleri & $\begin{array}{l}\text { Müze Ziyaretleri } \\
\text { Hakkındaki Görüşler }\end{array}$ & Tarih Öğretmenleri \\
\hline Müze Eğitimi & Üniversite Sanat Müzeleri & $\begin{array}{l}\text { Sanat Eğitimi Ortamı/ } \\
\text { müzeler }\end{array}$ & $\begin{array}{l}\text { Müze ziyareti yapan } \\
\text { öğrenci grupları ve müze } \\
\text { yöneticileri }\end{array}$ \\
\hline Müze Eğitimi & $\begin{array}{l}\text { Fransa Poitou- Charantes } \\
\text { Bölgesi'ndeki Müzeleri }\end{array}$ & Müze eğitimi faaliyetleri & - \\
\hline Müze Eğitimi & - & $\begin{array}{l}\text { İlköğretim Görsel } \\
\text { Sanatlar Eğitimi }\end{array}$ & $\begin{array}{l}\text { Öğrenci, Öğretmen ve } \\
\text { Müze Yetkilileri }\end{array}$ \\
\hline Müze Eğitimi & Rahmi M Koç Müzesi & Müzede Yetişkin Eğitimi & Yetişkinler \\
\hline Müze Eğitimi & $\begin{array}{l}\text { Almanya'da Çocuk } \\
\text { Müzeleri }\end{array}$ & $\begin{array}{l}\text { Çocuk Müzelerinde } \\
\text { eğitim }\end{array}$ & Çocuklar, Öğretmenler \\
\hline Müze Eğitimi & - & $\begin{array}{l}\text { Sanat Tarihi, Sanat } \\
\text { Eleştirisi }\end{array}$ & $\begin{array}{l}\text { Resim-İş Öğretmeni } \\
\text { Adayları }\end{array}$ \\
\hline Müze Eğitimi & Polis Müzeleri & $\begin{array}{l}\text { Polis Müzelerinde } \\
\text { Eğitim }\end{array}$ & Polis Memurları \\
\hline Tarih ve Kültür Bilinci & - & Görsel Sanatlar Dersi & İlkokul Öğrencileri \\
\hline Müze Eğitimi & Bursa Müzeleri & Müze Eğitiminin Önemi & Ortaokul Öğrencileri \\
\hline Müzede Öğrenme & $\begin{array}{l}\text { Anadolu Medeniyetleri } \\
\text { Müzesi }\end{array}$ & Heykel öğretimi & Lise Öğrencileri \\
\hline Müzede Öğrenme & $\begin{array}{l}\text { Anadolu Medeniyetleri } \\
\text { Müzesi ve Ankara Resim } \\
\text { ve Heykel Müzesi }\end{array}$ & Müzede Yaratıcı Drama & Ortaokul Öğrencileri \\
\hline
\end{tabular}

Müze Eğitimi alanındaki lisansüstü tezlerinin konulara göre dağılımına bakıldığında; Kültürel Çeşitlilik, Üniversite Eğitimi, Gezici Bavul Müze, Sanal Müze Kullanımı konularında sadece altı tez yapıldığı, diğer tezlerin müze eğitimi ve müzede öğrenme konularında yapıldığı saptanmıştır. Tezlerin \% 70'inden fazlası görsel sanatlar ve sosyal bilgiler derslerinde müze kullanımına ilişkindir. Tezlerde daha çok ilkokul, ortaokul - lise öğrencileri ve öğretmenler hedef grup olarak tercih edilmişlerdir. Müze Eğitimi alanında yapılan lisansüstü tezlerde örneklenen müzelere dağılımına bakıldığında; Bilim Müzesi, Arkeoloji Müzeleri (Kars Müzesi, Bolu Müzesi, Anadolu Medeniyetleri Müzesi, Çorum Müzesi), Çocuk ve Gençlik Müzeleri, Sanayi Müzeleri, Anıtkabir Müzesi, Pera Müzesi, Modena Müzesi/İtalya, Resim ve Heykel Müzesi, Sanal Müze, Çengelhan Rahmi Koç Müzesi, MEB 75. Y1l Cumhuriyet Eğitim Müzesi, Türk İslam Eserleri Müzesi, Atatürk ve Kurtuluş Savaşı Müzesi, İstanbul Modern Sanat Müzesi, Avusturya Lentos Kunts Museum-Linz, Trabzon Müzeleri, Üniversite Sanat Müzeleri, Fransa Poitou - Charantes Bölgesi`ndeki Müzeler, Rahmi Koç 
Müzesi, Polis Müzeleri, Bursa Müzeleri, Ankara Resim ve Heykel Müzesi, Tokat Müzesi, Üniversite Müzeleri olduğu görülmektedir.

\section{Sonuçlar ve Öneriler}

Müze eğitimi alanında ilerleyen yıllarda yapılacak tez çalışmaları için şu konular önerilebilir:

1. Müze eğitiminde materyal geliştirme

2. Müze eğitimi için uygulamalı web sayfası tasarımları

3. Müzede aile eğitimi

4. Müzede yetişkin eğitimi

5. Müze eğitiminde program geliştirme

6. Müze eğitiminde ölçme ve değerlendirme

7. Gençlerle müze eğitimi

8. Müzede yaratıcılık eğitimi

\section{Kaynakça}

Uluslararası Müzecilik Komitesi - ICOFOM (2010). Key concepts of museology (Museologie Anglais), ICOFOM.

(Çevrimiçi: http://icom.museum/fileadmin/ user_upload/pdf/Key_Concepts_of_Museology/Museologie_ Anglais_BD.pdf adresinden 12.11.2015 tarihinde edinilmiştir.) 


\section{Ek:1 Araştırma Kapsamında İncelenen Tezlerin Listesi}

\begin{tabular}{|c|c|c|}
\hline TEZIN ADI & $\begin{array}{l}\text { YAZARI ve DANIŞMANI } \\
\text { YILI VE DÜZEYİ }\end{array}$ & ENSTITÜSÜ PROGRAMI \\
\hline $\begin{array}{l}\text { Yedi On iki Yaş Arası Çocuklara Çizgi Film } \\
\text { Yöntemi ile Müze Eğitiminin Verilmesi }\end{array}$ & $\begin{array}{l}\text { Abdulgani Arıkan } \\
\text { Yrd.Doç.Dr. Can Şahin } \\
\text { 2001-Yüksek Lisans }\end{array}$ & $\begin{array}{l}\text { Selçuk Üniversitesi Sosyal Bilimler } \\
\text { Enstitüsü Resim Eğitimi Anabilim Dalı }\end{array}$ \\
\hline $\begin{array}{l}\text { Sosyal Bilgiler Öğretim Programında Müze } \\
\text { Eğitimiyle İliş̧kilendirilen Kazanımların } \\
\text { Gerçekleştirilmesine Yönelik Sosyal Bilgiler } \\
\text { Öğretmenlerinin Yaklaşımları (Tokat İli } \\
\text { Örneği) }\end{array}$ & $\begin{array}{l}\text { Abdulkerim Demir } \\
\text { Yrd.Doç.Dr. İsa Tak } \\
\text { 2015-Yüksek Lisans }\end{array}$ & $\begin{array}{l}\text { Gaziosmanpaşa Üniversitesi Eğitim } \\
\text { Bilimleri Enstitüsü İlköğretim Anabilim } \\
\text { Dalı Sosyal Bilgiler Eğitimi Yüksek Lisans } \\
\text { Programı }\end{array}$ \\
\hline $\begin{array}{l}\text { Müzede Öğrenmenin Öğrencilerin Görsel, } \\
\text { Duyuşsal ve Kinestetik Yönleri Üzerine } \\
\text { Etkileri (İlköğretim 6. Sinıf Öğrencileri } \\
\text { Üzerine Bir Uygulama) }\end{array}$ & $\begin{array}{l}\text { Altan Özeskici } \\
\text { Yrd.Doç.Himmet Gümrah } \\
\text { 2009-Yüksek Lisans }\end{array}$ & $\begin{array}{l}\text { Gazi Üniversitesi Eğitim Bilimleri } \\
\text { Enstitüsü Güzel Sanatlar Eğitimi A.B.D. } \\
\text { Resim-İş̧ Öğretmenliği Bilim Dalı }\end{array}$ \\
\hline $\begin{array}{l}\text { Çağdaş Sanat Müzeciliği Kapsamında } \\
\text { Türkiye'deki Müzecilik Hareketlerine Bir } \\
\text { Bakış }\end{array}$ & $\begin{array}{l}\text { Ayfer Karabıyık } \\
\text { Yrd.Doç.Dr. Fevziye Eyigör } \\
\text { 2007-Yüksek Lisans }\end{array}$ & $\begin{array}{l}\text { Atatürk Üniversitesi Sosyal Bilimler } \\
\text { Enstitüsü Resim Anasanat Dalı }\end{array}$ \\
\hline $\begin{array}{l}\text { Programlı ve Etkili Bir Müze Gezisi } \\
\text { İçin Geliştirilen Müze Eğitim Paketinin } \\
\text { Etkililiğinin Ölçülmesi (Ankara ili İlköğretim } \\
\text { I.Kademe 3. Sınıf Sanat Etkinlikleri Dersi } \\
\text { Örneği) }\end{array}$ & $\begin{array}{l}\text { Ayşe Güler } \\
\text { Doç.Dr. Serap Buyurgan } \\
\text { 2009-Doktora }\end{array}$ & $\begin{array}{l}\text { Gazi Üniversitesi Eğitim Bilimleri } \\
\text { Enstitüsü Güzel Sanatlar Eğitimi Bölümü } \\
\text { Resim-İs Öğretmenliği Anabilim Dalı }\end{array}$ \\
\hline $\begin{array}{l}\text { İlköğretim Okullarının Birinci Kademesinde } \\
\text { Görevli Sınıf Öğretmenlerinin Müzeleri } \\
\text { Görsel Sanatlar Eğitimi Dersinde } \\
\text { Kullanmalarına Yönelik Görüşleri (Ankara İli } \\
\text { Çankaya İlçesi Örneği) }\end{array}$ & $\begin{array}{l}\text { Azize Ebru Metan } \\
\text { Yrd.Doç.Gonca Yayan } \\
\text { 2007-Yüksek Lisans }\end{array}$ & $\begin{array}{l}\text { Gazi Üniversitesi Eğitim Bilimleri } \\
\text { Enstitüsü Güzel Sanatlar Eğitimi Bölümü } \\
\text { Resim-İs Öğretmenliği Anabilim Dalı }\end{array}$ \\
\hline $\begin{array}{l}\text { Müzelerle ve Tarihi Mekanlarla Tarih } \\
\text { Öğretimi: Tarih Öğretmenlerinin "Müze } \\
\text { Eğitimine" İlişkin Görüşleri }\end{array}$ & $\begin{array}{l}\text { Bahri Ata } \\
\text { Prof.Dr. Mustafa Safran } \\
\text { 2002-Doktora }\end{array}$ & $\begin{array}{l}\text { Gazi Üniversitesi Sosyal Bilimler Enstitüsü } \\
\text { Tarih Eğitimi Anabilim Dalı }\end{array}$ \\
\hline $\begin{array}{l}\text { Çağdaş Müze ve Kültürel Çeşitlilik: Arkeoloji } \\
\text { Müzesi Uzmanlarının Kültürel Çeşitliliğe } \\
\text { ilişkin Farkındalıklarının Değerlendirilmesi }\end{array}$ & $\begin{array}{l}\text { Ceren Karadeniz Prof.Dr. Bekir Onur } \\
\text { 2015- Doktora }\end{array}$ & $\begin{array}{l}\text { Ankara Üniversitesi Eğitim Bilimleri } \\
\text { Enstitüsü Güzel Sanatlar Eğitimi Anabilim } \\
\text { Dalı }\end{array}$ \\
\hline $\begin{array}{l}\text { Dünyada Çocuk Müzeleri ile Bilim, Teknoloji } \\
\text { ve Keşif Merkezlerinin İncelenmesi ve } \\
\text { Türkiye İçin Bir Çocuk Müzesi Modeli } \\
\text { Oluşturulması }\end{array}$ & $\begin{array}{l}\text { Ceren Karadeniz } \\
\text { Prof.Dr. Bekir Onur } \\
\text { 2009- Yüksek Lisans }\end{array}$ & $\begin{array}{l}\text { Ankara Üniversitesi Sosyal Bilimler } \\
\text { Enstitüsü Müze Eğitimi Anabilim Dalı }\end{array}$ \\
\hline $\begin{array}{l}\text { Üniversite Eğitiminde Üniversite Müzeleri ve } \\
\text { Yıldız Teknik Üniversitesi'nde Sanat Müzesi } \\
\text { Kurulması İçin Bir Ön Değerlendirme }\end{array}$ & $\begin{array}{l}\text { Cihan Çolak } \\
\text { Yrd.Doç.Dr. Hale Özkasım } \\
\text { 2008- Yüksek Lisans }\end{array}$ & $\begin{array}{l}\text { Yıldız Teknik Üniversitesi Sosyal Bilimler } \\
\text { Enstitüsü Sanat-Tasarım Ana Sanat Dalı } \\
\text { Müzecilik Yüksek Lisans Programı }\end{array}$ \\
\hline $\begin{array}{l}\text { Gezici Bavul Müze Uygulamaları ve Türkiye } \\
\text { İçin Bir Model Önerisi (Çorum Müzesi } \\
\text { Örneği) }\end{array}$ & $\begin{array}{l}\text { Cihan Şule Külük } \\
\text { Prof.Dr. Ayşe Çakır İlhan } \\
\text { 2015-Doktora }\end{array}$ & $\begin{array}{l}\text { Ankara Üniversitesi Eğitim Bilimleri } \\
\text { Enstitüsü Eğitimin Kültürel Temelleri } \\
\text { Anabilim Dalı Güzel Sanatlar Eğitimi } \\
\text { Programı }\end{array}$ \\
\hline $\begin{array}{l}\text { Müze Eğitimi ve Müze Ziyaretçilerinin } \\
\text { Atatürk ve Kurtuluş Savaşı Müzesi Ziyaretçi } \\
\text { Profili Aracılığıyla İncelenmesi }\end{array}$ & $\begin{array}{l}\text { Çağla Karademir Uysal } \\
\text { Prof.Dr. Bekir Onur } \\
\text { 2005-Yüksek Lisans }\end{array}$ & $\begin{array}{l}\text { Ankara Üniversitesi Sosyal Bilimler } \\
\text { Enstitüsü Müze Eğitimi Anabilim Dalı }\end{array}$ \\
\hline $\begin{array}{l}\text { İlköğretim 5. Sinıf Düzeyi Sanat Eğitiminde, } \\
\text { Müze Eğitiminin Öğrencilerin Tutumlarına } \\
\text { Etkisi }\end{array}$ & $\begin{array}{l}\text { Çiğdem Utku } \\
\text { Prof.Dr. Adnan Tepecik } \\
\text { 2008-Yüksek Lisans }\end{array}$ & $\begin{array}{l}\text { Gazi Üniversitesi Eğitim Bilimleri } \\
\text { Enstitüsü Güzel Sanatlar Eğitimi Resim-İş } \\
\text { Öğretmenliği Anabilim Dalı }\end{array}$ \\
\hline
\end{tabular}




\begin{tabular}{|c|c|c|}
\hline $\begin{array}{l}\text { Disiplin Temelli Sanat Eğitimi Modelinde } \\
\text { Müze Eğitimi ve Uygulamalarının Yeri ve } \\
\text { Ülkemizdeki Uygulama Olanakları }\end{array}$ & $\begin{array}{l}\text { Doğan Çelebi } \\
\text { Doç.Dr. Ali Seylan } \\
\text { 2012- Yüksek Lisans }\end{array}$ & $\begin{array}{l}\text { Ondokuz Mayıs Üniversitesi Eğitim } \\
\text { Bilimleri Enstitüsü Güzel Sanatlar Eğitimi } \\
\text { Anabilim Dalı }\end{array}$ \\
\hline $\begin{array}{l}\text { Müze ve İletişim; MSGSÜ Resim ve Heykel } \\
\text { Müzesi’nin Toplumla İletişimindeki Sorunları } \\
\text { ve Çözüm Önerileri }\end{array}$ & $\begin{array}{l}\text { Duygu Atalay } \\
\text { Yrd. Doç. Dr. Burcu Pelvanoğlu } \\
\text { 2012-Yüksek Lisans }\end{array}$ & $\begin{array}{l}\text { Mimar Sinan Güzel Sanatlar Üniversitesi } \\
\text { Sosyal Bilimler Enstitüsü Sanat Tarihi Ana } \\
\text { Bilim Dalı Müzecilik Programı }\end{array}$ \\
\hline $\begin{array}{l}\text { Sanal Sanat Müzelerinin ve Sanal Galerilerinin } \\
\text { Görsel Sanatlar Eğitimine Katkısı }\end{array}$ & $\begin{array}{l}\text { Elif Kalıncı } \\
\text { Yrd. Doç. Dr. Güzin Ayrancıoğlu } \\
\text { 2015-Yüksek Lisans }\end{array}$ & $\begin{array}{l}\text { Gazi Üniversitesi Eğitim Bilimleri } \\
\text { Enstitüsü Güzel Sanatlar Eğitimi Anabilim } \\
\text { Dalı }\end{array}$ \\
\hline $\begin{array}{l}\text { Sanal Müze Ziyaretlerinin Öğrencilerin } \\
\text { Bilişsel ve Duyuşsal Kazanımları Üzerindeki } \\
\text { Etkileri }\end{array}$ & $\begin{array}{l}\text { Emel Demirboğa } \\
\text { Prof.Dr. Serap Buyurgan } \\
\text { 2010-Yüksek Lisans }\end{array}$ & $\begin{array}{l}\text { Gazi Üniversitesi Eğitim Bilimleri } \\
\text { Enstitüsü Güzel Sanatlar Eğitimi Bölümü } \\
\text { Resim-İs Öğretmenliği Anabilim Dalı }\end{array}$ \\
\hline $\begin{array}{l}\text { Bilim Müzesi Ziyaretçilerinin Müze } \\
\text { İstasyonundan Öğrendiklerinin Bilgi } \\
\text { Hiyerarşisi ile Ölçülmesi ve İstasyondan } \\
\text { Öğrenilenlerin İstasyonun Tasarım Amacı İle } \\
\text { Karşıllaştırılması }\end{array}$ & $\begin{array}{l}\text { Erkan Yaşar } \\
\text { Dr. Cem Gürel } \\
\text { 2014-Yüksek Lisans }\end{array}$ & $\begin{array}{l}\text { Marmara Üniversitesi Eğitim Bilimleri } \\
\text { Enstitüsü Ortaögretim Fen ve Matematik } \\
\text { Alanı Eğitimi Anabilim Dalı Fizik } \\
\text { Öğretmenliği Bilim Dalı }\end{array}$ \\
\hline $\begin{array}{l}\text { Ortaokul (İlköğretim) 7. Sınıf Öğrencilerinin } \\
\text { Müze, Kültür, Tarih Alan Bilgisi ve Bilinç } \\
\text { Düzeylerinin İncelenmesi: Kars İli Örneği }\end{array}$ & $\begin{array}{l}\text { Ersin Sözver } \\
\text { Yrd. Doç. Dr. Yaşar Kop } \\
\text { 2015- Yüksek Lisans }\end{array}$ & $\begin{array}{l}\text { Kafkas Üniversitesi Sosyal Bilimler } \\
\text { Enstitüsü İlköğretim Anabilim Dalı Sosyal } \\
\text { Bilgiler Öğretimi Bilim Dalı }\end{array}$ \\
\hline $\begin{array}{l}\text { İlköğretim Okulları İkinci Kademe Programı } \\
\text { Resim-İş Dersinde Müze Eğitiminin Yeri ve } \\
\text { Önemi }\end{array}$ & $\begin{array}{l}\text { Fatih Varol } \\
\text { Doç.Dr. Adnan Tepecik } \\
\text { 2001- Yüksek Lisans }\end{array}$ & $\begin{array}{l}\text { Gazi Üniversitesi Eğitim Bilimleri } \\
\text { Enstitüsü Resim-İş Anabilim Dalı }\end{array}$ \\
\hline $\begin{array}{l}\text { Çocuk ve Gençlik Müzelerinde Barış Eğitimi } \\
\text { Programları }\end{array}$ & $\begin{array}{l}\text { Ferhat Koray Sağlam } \\
\text { Yrd. Doç. Dr. Kadriye T.Akmehmet } \\
\text { 2015- Yüksek Lisans }\end{array}$ & $\begin{array}{l}\text { Yıldız Teknik Üniversitesi Sosyal Bilimler } \\
\text { Enstitüsü Sanat ve Tasarım Ana Sanat Dalı } \\
\text { Müzecilik Yüksek Lisans Programı }\end{array}$ \\
\hline $\begin{array}{l}\text { Sanayi Müzelerinin Tarih Öğretiminde } \\
\text { Kullanım Durumu: Rahmi M. Koç Müzesi } \\
\text { Örneği }\end{array}$ & $\begin{array}{l}\text { Gözde Akyüz } \\
\text { Doç.Dr.Dursun Dilek } \\
\text { 2009- Yüksek Lisans }\end{array}$ & $\begin{array}{l}\text { Marmara Üniversitesi Eğitim Bilimleri } \\
\text { Enstitüsü Ortaöğretim Sosyal Alanlar } \\
\text { Eğitimi Anabilim Dalı Tarih Eğitimi Bilim } \\
\text { Dalı }\end{array}$ \\
\hline $\begin{array}{l}\text { Fotoğrafta Sanal Gerçeklik Ve Müzeler Yolu } \\
\text { İle Sanat Eğitimine Katkıları (Anıtkabir, } \\
\text { Anadolu Medeniyetleri Müzesi Uygulaması) }\end{array}$ & $\begin{array}{l}\text { Hami Onur Bingöl } \\
\text { Prof.Dr. Adnan Tepecik } \\
\text { 2008- Yüksek Lisans }\end{array}$ & $\begin{array}{l}\text { Gazi Üniversitesi Eğitim Bilimleri } \\
\text { Enstitüsü Güzel Sanatlar Eğitimi Anabilim } \\
\text { Dalı Resim-İș Öğretmenliği Bilim Dalı }\end{array}$ \\
\hline $\begin{array}{l}\text { Sanat Eğitimi Ortamı Olarak Üniversite Sanat } \\
\text { Müzelerinin İşlevi }\end{array}$ & $\begin{array}{l}\text { Hülya Şimşek } \\
\text { Prof.Dr. Serap Buyurgan } \\
\text { 2014- Doktora }\end{array}$ & $\begin{array}{l}\text { Gazi Üniversitesi Eğitim Bilimleri } \\
\text { Enstitüsü Güzel Sanatlar Eğitimi Anabilim } \\
\text { Dalı Resim-İş Öğretmenliği Bilim Dalı }\end{array}$ \\
\hline $\begin{array}{l}\text { Ortaokul Öğrencilerinin Sanat Gelişimininde } \\
\text { Müzelerin Etkisi }\end{array}$ & $\begin{array}{l}\text { Hüsniye Yıldırım Yrd. Doç. Bahattin } \\
\text { Odabaşı } \\
\text { 2015- Yüksek Lisans }\end{array}$ & $\begin{array}{l}\text { İstanbul Arel Üniversitesi Sosyal Bilimler } \\
\text { Enstitüsü Grafik Tasarını Anasanat Dalı }\end{array}$ \\
\hline $\begin{array}{l}\text { Müzeler ve Kültürel Çeşitlilik: İtalya'dan Bir } \\
\text { Vaka İncelemesi }\end{array}$ & $\begin{array}{l}\text { İnanç Civaz Oktar } \\
\text { Doç.Dr. Serhan Ada } \\
\text { 2015- Yüksek Lisans }\end{array}$ & $\begin{array}{l}\text { İstanbul Bilgi Üniversitesi Sosyal Bilimler } \\
\text { Enstitüsü Kültür Yönetimi Yüksek Lisans } \\
\text { Programı }\end{array}$ \\
\hline $\begin{array}{l}\text { Kültürel Öğelerin Öğretiminde Müze } \\
\text { Gezilerinin Önemi }\end{array}$ & $\begin{array}{l}\text { Melike Tuba Demirci } \\
\text { Yrd.Doç.Dr. Gülmisal Emiroğlu } \\
\text { 2009- Yüksek Lisans }\end{array}$ & $\begin{array}{l}\text { Selçuk Üniversitesi Sosyal Bilimler } \\
\text { Enstitüsü İlköğretim Ana Bilim Dalı Sınıf } \\
\text { Öğretmenliği Bilim Dalı }\end{array}$ \\
\hline $\begin{array}{l}\text { Gazi Üniversitesi Mesleki Eğitim Fakültesi } \\
\text { Prof.ÜlkerMuncuk Müzesi’nde Bulunan Metal } \\
\text { İpliklerle İşlenmiş Ürünlerin İncelenmesi }\end{array}$ & $\begin{array}{l}\text { Mine Can } \\
\text { Prof.Dr. Fatma Özcan } \\
\text { 2008-Sanatta Yeterlik Tezi }\end{array}$ & $\begin{array}{l}\text { Gazi Üniversitesi Eğitim Bilimleri } \\
\text { Enstitüsü El Sanatları Anabilim Dalı }\end{array}$ \\
\hline
\end{tabular}




\begin{tabular}{|c|c|c|}
\hline Türk Müzeciliğinin Tarihsel Gelişimi & $\begin{array}{l}\text { Murat Arık } \\
\text { Prof.Dr. S. Yücel Şenyurt } \\
\text { 2015- Yüksek Lisans }\end{array}$ & $\begin{array}{l}\text { Gazi Üniversitesi Sosyal Bilimler Enstitüsü } \\
\text { Arkeoloji Anabilim Dalı Arkeoloji Bilim } \\
\text { Dalı }\end{array}$ \\
\hline $\begin{array}{l}\text { Turistlerin Beklenti ve Deneyimleme } \\
\text { Kalitesinin Tavsiye Etme Kararına Etkisi: } \\
\text { Müze Ziyaretçileri Üzerine Bir Araştırma }\end{array}$ & $\begin{array}{l}\text { Mustafa Cevdet Altunel Doç.Dr. Ebru } \\
\text { Günlü } \\
\text { 2013-Doktora }\end{array}$ & $\begin{array}{l}\text { Dokuz Eylül Üniversitesi Sosyal Bilimler } \\
\text { Enstitüsü Turizm İşletmeciliği Anabilim } \\
\text { Dalı }\end{array}$ \\
\hline $\begin{array}{l}\text { İç Mekân Düzenlemesi ve Aktivite } \\
\text { Programlaması İçin Bir Öneri: İstanbul } \\
\text { Arkeoloji Müzeleri Bünyesinde Yer Alan } \\
\text { Çocuk Müzesi }\end{array}$ & $\begin{array}{l}\text { Müfide Bige Varlıer } \\
\text { Yrd.Doç.Carolyn Aslan } \\
\text { 2009- Yüksek Lisans }\end{array}$ & $\begin{array}{l}\text { Koç Üniversitesi Sosyal Bilimler Enstitüsü } \\
\text { Tarih Bölümü }\end{array}$ \\
\hline $\begin{array}{l}\text { Müze-Toplum İletişimi: MSGÜ Resim ve } \\
\text { Heykel Müzesinde Türk Resim Sanatı Üzerine } \\
\text { Eğitim Programları Önerisi }\end{array}$ & $\begin{array}{l}\text { Nalan Örki Zaremba } \\
\text { Prof.Dr. Tomur Atagök } \\
\text { 2005- Yüksek Lisans }\end{array}$ & $\begin{array}{l}\text { Yıldız Teknik Üniversitesi Sosyal Bilimler } \\
\text { Enstitüsü }\end{array}$ \\
\hline $\begin{array}{l}\text { Sosyal Bilgiler Dersinde Sanal Müze } \\
\text { Kullanımı ve Sosyal Bilgiler Öğretmeni } \\
\text { Adaylarının Sanal Müze Kullanımına Yönelik } \\
\text { Tutumları }\end{array}$ & $\begin{array}{l}\text { Neşe Peker } \\
\text { Yrd. Doç. Dr. Funda Varnacı Uzun } \\
\text { 2014- Yüksek Lisans }\end{array}$ & $\begin{array}{l}\text { Aksaray Üniversitesi Sosyal Bilimler } \\
\text { Enstitüsü Sosyal Bilgiler Eğitimi Anabilim } \\
\text { Dalı }\end{array}$ \\
\hline $\begin{array}{l}\text { Anadolu Medeniyetleri Müzesi Yıllıklarındaki } \\
\text { Müze Eğitimi Konuları Üzerine Bir } \\
\text { Değerlendirme }\end{array}$ & $\begin{array}{l}\text { Nihal Zor } \\
\text { Prof.Güler Akalan } \\
\text { 2010- Yüksek Lisans }\end{array}$ & $\begin{array}{l}\text { Gazi Üniversitesi Eğitim Bilimleri } \\
\text { Enstitüsü Güzel Sanatlar Eğitimi Anabilim } \\
\text { Dalı Resim-İş Öğretmenliği Bilim Dalı }\end{array}$ \\
\hline $\begin{array}{l}\text { Çengelhan Rahmi Koç Müzesi’nin Eğitim } \\
\text { Potansiyeli Açısından İncelenmesi }\end{array}$ & $\begin{array}{l}\text { Nihan Çiftçi } \\
\text { Prof.Dr. Hayat Erkanal } \\
\text { 2006- Yüksek Lisans }\end{array}$ & $\begin{array}{l}\text { Ankara Üniversitesi Sosyal Bilimler } \\
\text { Enstitüsü Müze Eğitimi Anabilim Dalı }\end{array}$ \\
\hline $\begin{array}{l}\text { MEB 75. Y1l Cumhuriyet Eğitim müzesi ve } \\
\text { Eğitim Potansiyeli }\end{array}$ & $\begin{array}{l}\text { Nil Koçak } \\
\text { Prof.Dr. Hayat Erkanal } \\
\text { 2006- Yüksek Lisans }\end{array}$ & $\begin{array}{l}\text { Ankara Üniversitesi Sosyal Bilimler } \\
\text { Enstitüsü }\end{array}$ \\
\hline Sosyal Bilgiler Öğretiminde Müze Kullanımı & $\begin{array}{l}\text { Nilüfer Filiz } \\
\text { Doç.Dr. Ali Yılmaz } \\
\text { 2010- Yüksek Lisans }\end{array}$ & $\begin{array}{l}\text { Marmara Üniversitesi Eğitim Bilimleri } \\
\text { Enstitüsü İlköğretim Anaabilim Dalı } \\
\text { Sosyal Bilgiler Öğretmenliği Bilim Dalı }\end{array}$ \\
\hline $\begin{array}{l}\text { İlköğretim I.Kademede Müze Eğitiminin } \\
\text { Görsel Sanatlar Kültürüne Etkileri }\end{array}$ & $\begin{array}{l}\text { Nurullah Atalay } \\
\text { Prof.Dr. Tayfun Akkaya } \\
\text { 2011-Doktora }\end{array}$ & $\begin{array}{l}\text { Marmara Üniversitesi Eğitim Bilimleri } \\
\text { Enstitüsü Güzel Sanatlar Eğitimi Anabilim } \\
\text { Dalı Resim-İş Eğitimi Bilim Dalı }\end{array}$ \\
\hline $\begin{array}{l}\text { Müze İncelemelerinin İlköğretim } \\
\text { Okullarındaki Görsel Sanatlar Eğitimine } \\
\text { Katkısı (Bolu İli Örneği) }\end{array}$ & $\begin{array}{l}\text { Oya Sarkan Tosun } \\
\text { Yrd.Doç.TuranEnginoğlu } \\
\text { 2009- Yüksek Lisans }\end{array}$ & $\begin{array}{l}\text { Dokuz Eylül Üniversitesi Eğitim Bilimleri } \\
\text { Enstitüsü Güzel Sanatlar Eğitimi Anabilim } \\
\text { Dalı Resim-İş Öğretmenliği Programı }\end{array}$ \\
\hline $\begin{array}{l}\text { Sanal Müze Arayüz Tasarımı (Ressam Ahmet } \\
\text { Yakupoğlu Sanal Müze Uygulaması) }\end{array}$ & $\begin{array}{l}\text { Ömer Zahid Kubat } \\
\text { Doç.Dr. Levent Mercin } \\
\text { 2012- Yüksek Lisans }\end{array}$ & $\begin{array}{l}\text { Dumlupınar Üniversitesi Sosyal Bilimler } \\
\text { Enstitüsü Grafik Ana Sanat Dalı }\end{array}$ \\
\hline $\begin{array}{l}\text { Müzelerin Eğitim Fonksiyonlarına Yönelik } \\
\text { Müze Yöneticilerinin Tutum ve Fikirleri }\end{array}$ & $\begin{array}{l}\text { Özden Yilmaz } \\
\text { Doç.Dr. Günseli Orhon } \\
\text { 2011- Yüksek Lisans }\end{array}$ & $\begin{array}{l}\text { Akdeniz Üniversitesi Sosyal Bilimler } \\
\text { Enstitüsü Müzecilik Ana Bilim Dalı }\end{array}$ \\
\hline $\begin{array}{l}\text { Ortaöğretim Görsel Sanatlar Eğitiminde Tarihi } \\
\text { Çevre ve Müze Bilincinin İncelenmesi }\end{array}$ & $\begin{array}{l}\text { Özlem Hacısalihoğlu } \\
\text { Yrd.Doç.Dr. Gülseren Pasin } \\
\text { 2013- Yüksek Lisans }\end{array}$ & $\begin{array}{l}\text { Dokuz Eylül Üniversitesi Eğitim Bilimleri } \\
\text { Enstitüsü Güzel Sanatlar Eğitimi Anabilim } \\
\text { Dalı Resim-İş Öğretmenliği Programı }\end{array}$ \\
\hline $\begin{array}{l}\text { Sosyal Bilgiler Dersinde Müze Eğitimine } \\
\text { Dayalı Öğretim Uygulamalarının Öğrencilerin } \\
\text { Akademik Başarısına ve Tutumlarına Etkisi }\end{array}$ & $\begin{array}{l}\text { Sebahat Çerkez } \\
\text { Yrd. Doç. Dr. Duran Aydınözü } \\
\text { 2011- Yüksek Lisans }\end{array}$ & $\begin{array}{l}\text { Kastamonu Üniversitesi Sosyal Bilimler } \\
\text { Enstitüsü İlköğretim Anabilim Dalı Sosyal } \\
\text { Bilgiler Eğitimi Bilim Dalı }\end{array}$ \\
\hline
\end{tabular}




\begin{tabular}{|c|c|c|}
\hline $\begin{array}{l}\text { İstanbul Modern Sanat Müzesi İle Avusturya } \\
\text { Lentos Kunts Museum Linz'in Eğitim Odaları } \\
\text { Etkinliklerinin 2009-2010 Döneminde } \\
\text { İncelenmesi ve Karşılaştırılması }\end{array}$ & $\begin{array}{l}\text { Selin Göksel } \\
\text { Prof.Dr. Ahmet Özol } \\
\text { 2010- Yüksek Lisans }\end{array}$ & $\begin{array}{l}\text { Marmara Üniversitesi Eğitim Bilimleri } \\
\text { Enstitüsü Güzel Sanatlar Ana Bilim Dalı } \\
\text { Resim-İş Öğretmenliği Bilim Dalı }\end{array}$ \\
\hline $\begin{array}{l}\text { Tarih Öğretmenlerinin Müze Ziyaretleri } \\
\text { Hakkındaki Görüşleri: Trabzon Örneği }\end{array}$ & $\begin{array}{l}\text { Selma Ekmekci } \\
\text { Prof.Dr. İsmail H. Demircioğlu } \\
\text { 2015- Yüksek Lisans }\end{array}$ & $\begin{array}{l}\text { Karadeniz Teknik Üniversitesi Eğitim } \\
\text { Bilimleri Enstitüsü Ortaöğretim Sosyal } \\
\text { Alanlar Eğitimi Anabilim Dalı Tarih } \\
\text { Eğitimi Bilim Dalı }\end{array}$ \\
\hline $\begin{array}{l}\text { Fransa Poitou- Charantes Bölgesi’ndeki } \\
\text { müzelerin müze eğitimi faaliyetlerinin } \\
\text { incelenmesi }\end{array}$ & $\begin{array}{l}\text { Serap Özdemir } \\
\text { Prof.Dr. Yaşar Selçuk Şener } \\
\text { 2015- Yüksek Lisans }\end{array}$ & $\begin{array}{l}\text { Ankara Üniversitesi Sosyal Bilimler } \\
\text { Enstitüsü Müze Eğitimi Anabilim Dalı }\end{array}$ \\
\hline $\begin{array}{l}\text { Türkiye'de Cumhuriyet Dönemi Müzecilik } \\
\text { Bağlamında Butik Müze }\end{array}$ & $\begin{array}{l}\text { Serpil Birsin } \\
\text { Doç.Dr. Nedret Yaşar } \\
\text { 2015- Yüksek Lisans }\end{array}$ & $\begin{array}{l}\text { İstanbul Kemerburgaz Üniversitesi Sosyal } \\
\text { Bilimler Enstitüsü Sanat ve Tasarım } \\
\text { Anasanat Dalı }\end{array}$ \\
\hline $\begin{array}{l}\text { İlköğretim Görsel Sanatlar Eğitimi Dersindeki } \\
\text { Müze Etkinliklerine Yönelik, Öğrenci, } \\
\text { Öğretmen ve Müze Yetkililerinin Görüşleri }\end{array}$ & $\begin{array}{l}\text { Sevim Kaya Koçak } \\
\text { Yrd.Doç.Dr. Gülgün Bangir Alpan } \\
\text { 2010- Yüksek Lisans }\end{array}$ & $\begin{array}{l}\text { Gazi Üniversitesi Eğitim Bilimleri } \\
\text { Enstitüsü Uygulamalı Sanatlar Eğitimi } \\
\text { Anabilim Dalı Mesleki Resim Eğitimi } \\
\text { Bilim Dalı }\end{array}$ \\
\hline $\begin{array}{l}\text { Müzelerin Yetişkin Eğitiminde Kullanılmasına } \\
\text { Yönelik Bir Program Denemesi - Rahmi Koç } \\
\text { Müzesi İletişim Araçları Örneği - }\end{array}$ & $\begin{array}{l}\text { Sibel Yenigün Kapan } \\
\text { Yrd.Doç.Dr. Levent Deniz } \\
\text { 2011- Yüksek Lisans }\end{array}$ & $\begin{array}{l}\text { Marmara Üniversitesi Eğitim Bilimleri } \\
\text { Enstitüsü Eğitim Bilimleri Ana Bilim Dalı } \\
\text { Halk Eğitimi Bilim Dalı }\end{array}$ \\
\hline $\begin{array}{l}\text { Tüketicilerin Müze Ziyaret Alışkanlıkları ve } \\
\text { Müze Tercihlerini Etkileyen Faktörler Üzerine } \\
\text { Bir Araştırma }\end{array}$ & $\begin{array}{l}\text { Süleyman Sözer Kırca } \\
\text { Yrd.Doç.Dr. Nilgün Sarıkaya } \\
\text { 2008- Yüksek Lisans }\end{array}$ & $\begin{array}{l}\text { Sakarya Üniversitesi Sosyal Bilimler } \\
\text { Enstitüsü İşletme Anabilim Dalı Üretim } \\
\text { Yönetimi ve Pazarlama Bilim Dalı }\end{array}$ \\
\hline Türkiye'de Özel Müzecilik ve Baksı Müzesi & $\begin{array}{l}\text { Şemsinur Çelik } \\
\text { Doç.Dr. Mustafa Küçüköner } \\
\text { 2012- Yüksek Lisans }\end{array}$ & $\begin{array}{l}\text { Atatürk Üniversitesi Sosyal Bilimler } \\
\text { Enstitüsü Resim Anasanat Dalı }\end{array}$ \\
\hline $\begin{array}{l}\text { Avrupa'da Çocuk Müzeleri ve Müze } \\
\text { Eğitimi "Almanya Örneği" / Child } \\
\text { museum in europeandmuseumeducation } \\
\text { "theGermanExample" }\end{array}$ & $\begin{array}{l}\text { Şule Zilcioğlu } \\
\text { Prof.Dr. Bekir Onur } \\
\text { 2008- Yüksek Lisans }\end{array}$ & $\begin{array}{l}\text { Ankara Üniversitesi Sosyal Bilimler } \\
\text { Enstitüsü Müze Eğitimi Anabilim Dalı }\end{array}$ \\
\hline $\begin{array}{l}\text { Atatürk Döneminde (1923-1938) Eski Eser } \\
\text { Politikaları ve Türkiye'de Yapılan Kazı } \\
\text { Çalışmaları }\end{array}$ & $\begin{array}{l}\text { Şükrü Ünar } \\
\text { Prof.Dr. Özdemir Koçak } \\
\text { 2013- Yüksek Lisans }\end{array}$ & $\begin{array}{l}\text { Selçuk Üniversitesi Sosyal Bilimler } \\
\text { Enstitüsü Tarih Anabilim Dalı Tarih Bilim } \\
\text { Dalı }\end{array}$ \\
\hline $\begin{array}{l}\text { Resim-İş Eğitimi Anabilim Dallarında Müze } \\
\text { Eğitiminin Sanat Tarihi, Sanat Eleştirisi ve } \\
\text { Anasanat Atölyelerinde Uygulamalara Etkisi }\end{array}$ & $\begin{array}{l}\text { Taylan Çetin } \\
\text { Yrd.Doç.Dr.EmineHalıçınarlı } \\
\text { 2006- Yüksek Lisans }\end{array}$ & $\begin{array}{l}\text { Dokuz Eylül Üniversitesi Eğitim Bilimleri } \\
\text { Enstitüsü Güzel Sanatlar Eğitimi Anabilim } \\
\text { Dalı Resim-İş Öğretmenliği Programı }\end{array}$ \\
\hline $\begin{array}{l}\text { İlköğretim I. Kademe Görsel Sanatlar } \\
\text { Dersinde Müze Eğitmeninin Tarih ve Kültür } \\
\text { Bilinci Oluşturulmasındaki Önemi }\end{array}$ & $\begin{array}{l}\text { Timuçin Akyürek } \\
\text { Yrd.Doç.Dr. Sema Bilici } \\
\text { 2011- Yüksek Lisans }\end{array}$ & $\begin{array}{l}\text { Gazi Üniversitesi Eğitim Bilimleri } \\
\text { Enstitüsü Güzel Sanatlar Eğitimi Bölümü } \\
\text { Resim-İş Eğitimi Bilim Dalı }\end{array}$ \\
\hline $\begin{array}{l}\text { İlköğretim II. Kademede Müze Eğitiminin } \\
\text { Önemi Üzerine Araştırma (Bursa Örneğinde) }\end{array}$ & $\begin{array}{l}\text { Tuğba Gürkan } \\
\text { Yrd.Doç.Dr. Bedri Yalman } \\
\text { 2004- Yüksek Lisans }\end{array}$ & $\begin{array}{l}\text { Uludağ Üniversitesi Sosyal Bilimler } \\
\text { Enstitüsü Güzel Sanatlar Eğitimi Anabilim } \\
\text { Dalı Resim-İş Eğitimi Bilim Dalı }\end{array}$ \\
\hline $\begin{array}{l}\text { Anadolu Medeniyetleri Müzesinde Yer } \\
\text { Alan Tarih Öncesi Dönemlere Ait Kadın } \\
\text { Heykellerinin Lise Ögrencilerinin Heykel } \\
\text { Uygulamalarına Etkisi }\end{array}$ & $\begin{array}{l}\text { Uğur Halıcı } \\
\text { Yrd. Doç.Dr. Ayşe Okur } \\
\text { 2015- Yüksek Lisans }\end{array}$ & $\begin{array}{l}\text { Necmettin Erbakan Üniversitesi Eğitim } \\
\text { Bilimleri Enstitüsü Güzel Sanatlar Eğitimi } \\
\text { Anabilim Dalı Resim-İş Eğitimi Bilim Dalı }\end{array}$ \\
\hline $\begin{array}{l}\text { Kültür Varlıklarının Korunması ve Toplumsal } \\
\text { Kültürel Bilincin Arttırılması Konusunda } \\
\text { Üniversitelerin Rolü }\end{array}$ & $\begin{array}{l}\text { Uygar Güler } \\
\text { Arkeolog Nihal Metin } \\
\text { 2012- Uzmanlık }\end{array}$ & $\begin{array}{l}\text { T.C. Kültür ve Turizm Bakanlığı Kültür } \\
\text { Varlıkları ve Müzeler Genel Müdürlüğü }\end{array}$ \\
\hline
\end{tabular}




\begin{tabular}{|c|c|c|}
\hline $\begin{array}{l}\text { Ankara'daki Müzelerde Yaratıcı Drama } \\
\text { Etkinlikleri ve Ankara Resim ve Heykel } \\
\text { Müzesinde Yaratıcı Drama Önerisi }\end{array}$ & $\begin{array}{l}\text { Ümmü Hale Hamurculu } \\
\text { Doç.Dr. Ayşe Okvuran } \\
\text { 2016- Yüksek Lisans }\end{array}$ & $\begin{array}{l}\text { Ankara Üniversitesi Sosyal Bilimler } \\
\text { Enstitüsü Disiplinlerarası Müze Eğitimi } \\
\text { Anabilim Dalı }\end{array}$ \\
\hline $\begin{array}{l}\text { Sosyal Bilgiler Öğretiminde Müze } \\
\text { Kullanımına İlişkin Öğretmen ve Öğrenci } \\
\text { Görüşlerinin İncelenmesi (Afyonkarahisar } \\
\text { Müzeleri) }\end{array}$ & $\begin{array}{l}\text { Yavuz Kisa } \\
\text { Doç.Dr. Ahmet Ali Gazel } \\
\text { 2012- Yüksek Lisans }\end{array}$ & $\begin{array}{l}\text { Afyon Kocatepe Üniversitesi Sosyal } \\
\text { Bilimler Enstitüsü İlköğretim Anabilim } \\
\text { Dalı }\end{array}$ \\
\hline $\begin{array}{l}\text { Türk ve İslam Eserleri Müzesi’nde Milli } \\
\text { Eğitim Müfredatı Doğrultusunda ilköğretim } \\
\text { Öğrencilerine Yönelik Eğitim Programı } \\
\text { Hazırlama Projesi }\end{array}$ & $\begin{array}{l}\text { Yeliz Çetindağ Kuşan } \\
\text { Öğr.Gör.ZehraErkün Oruçoğlu } \\
\text { 2005- Yüksek Lisans }\end{array}$ & $\begin{array}{l}\text { Yıldız Teknik Üniversitesi Sosyal Bilimler } \\
\text { Enstitüsü }\end{array}$ \\
\hline $\begin{array}{l}\text { İlköğretim 7. Sınıf Görsel Sanatlar Dersi } \\
\text { Röprodüksiyon Konusunun, Müze Eğitim } \\
\text { Atölyeleri Ortamında İşlenmesinin } \\
\text { İncelenmesi }\end{array}$ & $\begin{array}{l}\text { Yeşim Güzin Çakan } \\
\text { Prof.Dr. Ümran Bulut } \\
\text { 2011- Yüksek Lisans }\end{array}$ & $\begin{array}{l}\text { Marmara Üniversitesi Eğitim Bilimleri } \\
\text { Enstitüsü Güzel Sanatlar Eğitimi Anabilim } \\
\text { Dalı Resim-İş Öğretmenliği Bilim Dalı }\end{array}$ \\
\hline $\begin{array}{l}\text { Müzecilik Eğitiminde Yeni Eğilimler } \\
\text { Türkiye'de Müzecilik ve Mesleki Eğitim }\end{array}$ & $\begin{array}{l}\text { Yeşim Kartaler Çınar } \\
\text { Yrd.Doç.Dr. Hale Özkasım } \\
\text { 2009- Yüksek Lisans }\end{array}$ & $\begin{array}{l}\text { Yıldız Teknik Üniversitesi Sosyal Bilimler } \\
\text { Enstitüsü Sanat ve Tasarım Ana Sanat Dalı }\end{array}$ \\
\hline $\begin{array}{l}\text { Sürdürülebilirlik ve İktidar Bağlamında Sözel } \\
\text { Belleğin Türk Müzelerinde Kullanımı }\end{array}$ & $\begin{array}{l}\text { Zehra Sema Demir } \\
\text { Prof.Dr. M. Öcal Oğuz } \\
\text { 2010-Doktora }\end{array}$ & $\begin{array}{l}\text { Gazi Üniversitesi Sosyal Bilimler Enstitüsü } \\
\text { Türk Dili ve Edebiyatı Anabilim Dalı Türk } \\
\text { Halk Edebiyatı Bilim Dalı }\end{array}$ \\
\hline $\begin{array}{l}\text { Müzelerde Görsel Kültür Çalışmalarının } \\
\text { Postmodern Sanat Eğitimi Bağlamında } \\
\text { Yapılandırılmasına İlişkin Hazırlanan } \\
\text { Eğitim Paketinin Eğitim evlerinde } \\
\text { Görevli Uzmanların Görüşlerine Göre } \\
\text { Değerlendirilmesi }\end{array}$ & $\begin{array}{l}\text { Zekiye Çıldır } \\
\text { Prof.Dr. Ayşe Çakır İlhan } \\
\text { 2015-Doktora }\end{array}$ & $\begin{array}{l}\text { Ankara Üniversitesi Eğitim Bilimleri } \\
\text { Enstitüsü Eğitimin Kültürel Temelleri } \\
\text { Anabilim Dalı Güzel Sanatlar Eğitimi } \\
\text { Bilim Dalı }\end{array}$ \\
\hline $\begin{array}{l}\text { Öğretmenlerle Müzede Yetişkin Eğitimi - Feza } \\
\text { Gürsey Bilim Merkezi Örneği - }\end{array}$ & $\begin{array}{l}\text { Zekiye Çıldır } \\
\text { Prof.Dr.BernaAlpagut } \\
\text { 2007- Yüksek Lisans }\end{array}$ & $\begin{array}{l}\text { Ankara Üniversitesi Sosyal Bilimler } \\
\text { Enstitüsü Müze Eğitimi Anabilim Dalı }\end{array}$ \\
\hline $\begin{array}{l}\text { Müze Eğitimi Alanında Yapılmış Olan } \\
\text { Lisansüstü Tezlerin ve Bitirme Projelerinin } \\
\text { Belirlenen Ölçütlere Göre İncelenmesi }\end{array}$ & $\begin{array}{l}\text { Zerrin Salbacak } \\
\text { Prof.Dr. Gelengül Haktanır } \\
\text { 2011- Yüksek Lisans }\end{array}$ & $\begin{array}{l}\text { Ankara Üniversitesi Sosyal Bilimler } \\
\text { Enstitüsü Müze Eğitimi Anabilim Dalı }\end{array}$ \\
\hline $\begin{array}{l}\text { İlköğretim Birinci Kademe Görsel Sanatlar } \\
\text { Eğitimi Müze Bilinci Öğrenme Alanında } \\
\text { Materyal Kullanımının Etkisi ve Uygulanması }\end{array}$ & $\begin{array}{l}\text { Zülfü Tan } \\
\text { Yrd.Doç.Mehmet Büyükçanga } \\
\text { 2009- Yüksek Lisans }\end{array}$ & $\begin{array}{l}\text { Selçuk Üniversitesi Sosyal Bilimler } \\
\text { Enstitüsü Güzel Sanatlar Eğitimi Ana } \\
\text { Bilim Dalı Resim-İş Öğretmenliği Bilim } \\
\text { Dalı }\end{array}$ \\
\hline $\begin{array}{l}\text { Polis Müzeleri ve Polis Müzelerinde Müze } \\
\text { Eğitimi }\end{array}$ & $\begin{array}{l}\text { Teoman Onur Emeksizoğlu } \\
\text { Yrd.Doç.Dr. Müge Artar } \\
\text { 2007- Yüksek Lisans }\end{array}$ & $\begin{array}{l}\text { Ankara Üniversitesi Sosyal Bilimler } \\
\text { Enstitüsü Müze Eğitimi Anabilim Dalı }\end{array}$ \\
\hline $\begin{array}{l}\text { Öğretmen adaylarının Sosyal Bilgiler } \\
\text { Öğretiminde müze kullanımına ilişkin } \\
\text { görüşlerinin incelenmesi }\end{array}$ & $\begin{array}{l}\text { Samet Kamçı } \\
\text { Yrd.Doç.Dr. Hatice Memişoğlu } \\
\text { 2015- Yüksek Lisans }\end{array}$ & $\begin{array}{l}\text { Abant İzzet Baysal Üniversitesi / Eğitim } \\
\text { Bilimleri Enstitüsü / İlköğretim Anabilim } \\
\text { Dalı/ Sosyal Bilgiler Öğretmenliği Bilim } \\
\text { Dalı }\end{array}$ \\
\hline
\end{tabular}

